\title{
Application Of Pair Share Think Learning Model To Improve Critical Thinking Ability In Social Science Science
}

\author{
Tietien Harfuthien \\ SMPN 2 Gresik \\ e-mail: tietienharfuthien1975@gmail.com
}

\begin{abstract}
The purpose of this study is to describe how to improve social science critical thinking skills by applying Think Pair Share learning model. This study uses a classroom action research method. The subjects of this study were class VIIIA students of SMP Negeri 2 Gresik totaling 32 students. The study used three research instruments, namely tests, observations and interviews. Based on the results of observations, obtained data that the highest average social science critical thinking skills of students in the first cycle is $60 \%$ and the lowest is $25 \%$. While the second cycle increased, the highest average student's social science critical thinking ability became $90 \%$ and the lowest $70 \%$. From these results it can be concluded that the application of the think pair share learning model can improve the critical thinking skills of social science grade VIIIA students of SMP Negeri 2 Gresik.
\end{abstract}

Keywords: Social Science, Critical thinking skills, Think pair share learning models

\section{INTRODUCTION}

Learning is a business process carried out by someone to obtain a change in behavior as a result of interaction with their environment in fulfilling their needs (Daryanto, 2010).

Social studies learning activities in junior high school are not only aimed at developing intellectual abilities or mastery of students' concepts but also developing process skills, scientific attitudes, curiosity, working together and respecting others. Therefore, a teacher should not only provide a set of knowledge in the form of facts, concepts or principles, but also provide an opportunity for students to find out or obtain their own knowledge through their experience so that expected social learning goals can be achieved. It is expected that the implementation of social studies in junior high school can help students in understanding the surrounding environment, have a scientific attitude and solve the problems it faces to further be applied in daily life. 
By paying attention to the social studies learning objectives, social studies learning should emphasize the existence of activities and interactions among students to motivate each other and help each other both in mastering the subject matter, solving problems, obtaining and processing information in his mind in accordance with the steps of the scientific method, and lure students to think critically in order to achieve maximum learning outcomes. In fact, in the field, things are the opposite of the explanation above found. Based on the observations of researchers when teaching and the results of interviews with researchers with fellow social studies teachers, information was obtained that the level of students' critical thinking skills for social studies subjects was still low. This can be seen from the level of students' critical thinking skills in everyday learning in class VIIIA of the State Junior High School 2 Gresik totaling 32 students, only $20 \%$ of students were able to apply indicators of critical thinking during learning activities.

On the basis of the above problems the researcher carried out classroom action research to improve social science critical thinking skills by applying the think pair share learning model. The learning model of think pair share is effective in improving students' thinking, because the learning model of think pair share gives students more time to think, answer and help each other (Julianto, 2011). Think pair share learning model, gives opportunities to students work alone and work with other people in the group. In this case the optimization of student participation can be seen so that the answers appear spontaneously which can contribute to the group they are facing. So here the teacher acts as a guide, facilitator and motivator. Think Pair Share is a thinking learning model paired in small groups that are heterogeneous both academically and sexually (Ibrahim, 2000). With this small group, students are expected to be more active in completing tasks and all members will feel involved in it. So that all students can express their ideas that have an impact on improving social science critical thinking skills and learning outcomes. Critical thinking is reasoned and reflective thinking by emphasizing decision making about what to believe or do (Williawati, 2009). Indicators of critical thinking skills can be derived from critical activities students develop the ability to observe or observe, analyze, generalize, identify and solve problems. By applying the learning model think pair share in social studies learning makes it easier for students to explore indicators of critical thinking skills.

\section{METHOD}

researchuses a class action research design. Classroom Action Research uses a cycle model with stages of planning, action, observation and reflection. This study was conducted in two cycles, each cycle consisting of 2 meetings and one final cycle evaluation. The research subjects were class VIIIA students of SMP Negeri 2 Gresik totaling 32 students consisting of 14 male students and 18 female students. The location of the study was at SMP Negeri 2 Gresik. During this research the researcher acted as a teacher and collaborated with colleagues who acted as observers. 
Planning begins with analyzing the curriculum, arranging syllabi and Learning Plans (RPP), student worksheets (LKS), and final cycle evaluations. Compile research instruments, namely, teacher activity observation sheets and student activity observation sheets. Establish indicators of research achievement. Implementation of actions taken, among others, carry out learning activities that have been made and collect data needed in research. Observations were made by colleagues as observers. Observer observes the course of learning in class by using instruments that have been provided by researchers. The things that are observed are the activities of students and teachers, as well as the obstacles experienced during the application of the learning model think pair share. Reflections were carried out by researchers and observers. Reflection is carried out in the framework of finding weaknesses and shortcomings in the practice of learning undertaken to find solutions and strengthening learning that are considered to be less than optimal.

Data was collected using test techniques, observation sheets and interviews. Tests are carried out before and after learning. Observation of student and teacher activities is carried out simultaneously with the implementation of learning activities. The observation was carried out by the observer using an observation sheet. The data obtained are then analyzed using data: Analysis of the activities of students and teachers based on the results of the observation sheet during the learning process to see the suitability between planning and implementing actions. Analysis of the results of critical thinking learning is based on the results of an objective assessment, so a scoring system is needed. The value obtained by students shows the percentage of students' mastery of the subject matter that has been taught.

The valuation formula is as follows:

$$
\mathrm{NP}=\underline{\mathrm{R}} \times 100 \mathrm{BC}
$$

Oriented on the valuation formula above, NP (percent value sought) is the final value of the student. To see the success of the actions taken is to compare the learning outcomes of the first cycle with the second cycle. With the increase in learning outcomes in the second cycle compared to cycle one, it means that students' critical thinking skills have also increased.

\section{RESULT AND DISCUSSION}

This classroom action research was conducted in class VIIIA of SMP Negeri 2 Gresik. This research was conducted in 2 cycles consisting of 6 meetings. In the first cycle, the subject matter is changes in space and interactions between spaces due to natural factors, including 3 meetings including daily tests. And in the second cycle the subject of the influence of the development of Science and Technology on changes in space, includes 3 meetings including daily tests. Within 1 week the time needed for each meeting is $2 \times 40$ minutes. 


\section{Implementation of research}

Researchers carry out the learning process in accordance with the RPP which applies the learning model think pair share. The implementation begins with inviting students to think through question and answer, pairing in groups and sharing with the whole class. Explanation of each stage as follows:

Stage 1: Thinking (thinking) that is the teacher asks questions or issues related to the lesson then students are asked to think about the question or issue independently for a while.

Stage 2: Pairing, namely the teacher asks students to pair up with other students to discuss what they have thought in the first stage. This stage of interaction is expected to be able to share answers if a question or various ideas have been submitted, after students pair up then they are made into groups of four so that each of the questions and ideas can be considered together. At this stage the group works based on the instructions on the LKS, if a specific problem has been identified the teacher gives 4-5 minutes to discuss the learning outcomes.

Stage 3: In the final stage, the teacher asks the partner or group representative to share with the class what they have discussed. It is done by taking turns in each group representative and continuing to about a quarter of the representatives who have the opportunity to report. At this stage students will appear critical thinking. When one friend of a friend from another group read the results of the experiment.

In its implementation students are very excited. But in the first cycle the activities of the students were less directed because the students were not used to doing learning like this and the students did not understand how to find themselves a problem that they wanted to solve. While in cycle II students were no longer ashamed to give answers and input on the problems presented. Many students already understand the steps in learning think pair share.

At the end of the lesson students with the help of the teacher conclude the subject matter. The teacher gives awards for hard work and individual and group learning outcomes. As long as students work the teacher is only a facilitator and student guide. When presenting the teacher emphasizes the concepts that are considered important and at the end of the class discussion activities the teacher guides students to draw conclusions. The closing activity of learning is students working on the final learning evaluation.

\section{Reflection of Cycle I}

To find out the level of thinking ability of students in social studies learning, after conducting learning activities the first cycle of students is given a test of critical thinking skills of 10 items. Questions refer to indicators of students' thinking abilities. After being given the ability to think test questions on Cycle I, it was seen that the application of the think pair share learning model made students more excited than before. But the use of time at this meeting was less effective and in its implementation was less directed so the class became noisy. 
In the implementation of learning cycle II, improvements were made to correct deficiencies in cycle I. Some things that the teacher did were like explaining the problem or exposing students to the problem and explaining the procedure of think pair share to students in order to manage time. The teacher further directs students to find answers to problems, and motivates many students. Students are emphasized to make more use of the time when filling in the LKS. Teachers are more objective in supervising student activities in the implementation of observations. The teacher provides reinforcement of the material that has been studied. Reflection is done after the daily test is carried out. The results of reflection in the first cycle found that of the 20 students, the indicator of students' critical thinking ability was the highest, namely $60 \%$ in the problem solving indicator and the lowest was $25 \%$ in the analyzing indicator. Thus the results of students' critical thinking skills are still low and have an impact on learning outcomes can not be categorized as complete The achievement of classical completeness in the first cycle is due to students learning for the first time using the think pair share learning model, so there are still many students who are confused and have difficulty . Besides that the teacher (researcher) is also less able to condition students in groups. Thus further actions need to be held, in addition to correcting the deficiencies that still exist also aiming to strengthen the decision of the results of the research in connection with this matter, it will hold a second cycle of social studies learning later.

\section{Cycle II Reflection}

After conducting learning activities during the second cycle each indicator of critical thinking students has increased. Students are familiar with ordinary questions that require the ability to identify, solve problems, analyze, and generalize social science questions.

In the second cycle it was seen that students were very enthusiastic about learning, many asked questions and enthusiasm answered. Therefore it is very necessary to familiarize students with solving problems that require students' ability to think critically, so that students not only memorize material concepts but understand what is meant by a science in social studies learning.

\section{Student Activities}

In the first cycle of meeting 1 it was the first experience for students in following the learning process of the learning model think pair share. On average there are still many students who are noisy, pay less attention to teachers, less orderly in groups and less collaborating into heterogeneous study groups when working on LKS. Student participation in presenting is already quite good, although it is crowded but they dare to come forward, in collaborating with student worksheets, they are already active.

In cycle II students look active and are able to respond to the results of discussions from other groups. Students are eager to get an award from the teacher. All students are actively involved in discussions, experiments and question and answer. Students have followed the rules. Even they were able to present their work in front of the class shamelessly. This can be seen in the following table: 
Table 1.

Analysis of Results of Observation of Student Activity Cycle I and Cycle II

\begin{tabular}{|l|l|l|l|l|}
\hline \multicolumn{1}{|c|}{ Cycle } & \multicolumn{1}{|c|}{ Meeting } & \multicolumn{1}{c|}{ Amount } & \multicolumn{1}{c|}{ Category } \\
\hline I & Meeting 1 & 20 & $50 \%$ & Less \\
\hline & Meeting 2 & 27 & $67.5 \%$ & Enough \\
\hline II & Meeting 1 & 34 & $85 \%$ & Very Good \\
\hline & Meeting 2 & 37 & $92.5 \%$ & Very Good \\
\hline
\end{tabular}

From the table above it can be seen student activities during the learning process by applying the think pair and share cooperative learning model has increased. It can be seen from the first cycle of meeting 1 that is $50 \%$ with less categories. In the first cycle of meeting 2, there was an increase of $67.5 \%$ with sufficient categories. In the second cycle of meeting 1 student activity increased again to $85 \%$ with a very good category. In the second cycle of meeting 2 the learning process can be said to be very good because the percentage increased to $92.5 \%$.

\section{Analysis of Teacher Activity Observation Results}

From the observation of the first cycle, the teacher had almost done all stages of think pair share. The teacher guides students to conduct experiments and discussions in learning activities. However, the teacher has not directed students to find problems so there are still many students who are looking for them in the printed book. The teacher also has not made material reinforcement at the end of the lesson. This can be seen in the following table:

Table 2

Analysis of Observation Results of Teacher Activity Cycle I and Cycle II

\begin{tabular}{|l|l|l|l|l|}
\hline \multicolumn{1}{|c|}{ Cycle } & \multicolumn{1}{c|}{ Meeting } & \multicolumn{1}{c|}{ Amount } & \multicolumn{1}{c|}{ Category } \\
\hline I & Meeting 1 & 22 & $55 \%$ & Less \\
\hline & Meeting 2 & 27 & $67.5 \%$ & Enough \\
\hline II & Meeting 1 & 32 & $80.0 \%$ & Very Good \\
\hline & Meeting 2 & 34 & $87.5 \%$ & Very Good \\
\hline
\end{tabular}

From the table above shows the activity of teachers during the learning process with the application of the learning model think pair share has increased. It can be seen from the first cycle of meeting 1 that is $55 \%$ with less categories. In the first cycle of meeting 2 there was an increase of $67.5 \%$ with sufficient categories. In the second cycle of meeting 1 student activity increased again to $80.0 \%$ with a very good category. In the second cycle of meeting 2 the learning process can be said to be very good because the percentage increased to $87.5 \%$.

\section{The Results of Students 'Critical Thinking Ability}

In the first cycle the results of the students' thinking ability test are still lacking, it can be seen the average results of critical thinking skills in each indicator are highest, namely $65 \%$ in the problem-solving indicator, indicator generalizes that is $38 \%$, identifying indicators reach $31 \%$ of 32 students. Students' thinking ability is very lacking especially in analyzing story problems which only reaches $25 \%$. Students are 
only familiar with ordinary questions that only prioritize aspects of remembering concepts. This can be seen in the following table:

Table 3

Results Score Indicators Critical Thinking Cycle I

\begin{tabular}{|l|l|l|l|l|}
\hline No & \multicolumn{1}{|c|}{ Indicators } & $\begin{array}{c}\text { Students } \\
\text { Complete }\end{array}$ & \multicolumn{1}{|c|}{$\begin{array}{c}\text { Students Not } \\
\text { Complete }\end{array}$} & Presentation \\
\hline 1 & Identify concepts & 10 & 22 & $31 \%$ \\
\hline 2 & Solve problems & 21 & 11 & $65 \%$ \\
\hline 3 & Analyze & 8 & 24 & $25 \%$ \\
\hline 4 & generalize & 12 & 20 & $38 \%$ \\
\hline
\end{tabular}

From the table above, the teacher must often familiarize students with solving problems that require students' ability to think critically, so that students not only memorize material concepts but understand what the meaning of a science is while in cycle II. It can be seen that the average student learning outcomes in critical thinking increases compared to the first cycle, namely in identifying $81 \%$, in solving problems $91 \%$, analyzing $75 \%$ and generalizing reaching $81 \%$. This can be seen in the following table:

\section{Table 4}

\section{Results Score Indicator Critical Thinking Cycle II}

\begin{tabular}{|l|l|l|l|l|}
\hline No & \multicolumn{1}{|c|}{ Indicators } & $\begin{array}{c}\text { Students } \\
\text { Complete }\end{array}$ & \multicolumn{1}{|c|}{$\begin{array}{c}\text { Students Not } \\
\text { Complete }\end{array}$} & Presentation \\
\hline 1 & Identify concepts & 26 & 6 & $81 \%$ \\
\hline 2 & Solve problems & 29 & 3 & $91 \%$ \\
\hline 3 & Analyze & 24 & 8 & $75 \%$ \\
\hline 4 & generalize & 26 & 6 & $81 \%$ \\
\hline
\end{tabular}

In the second cycle the highest critical thinking skills of students is $91 \%$ in the problem solving indicators and the lowest is $75 \%$ in the analyzing indicators. From cycle I to cycle II it can be seen that the application of cooperative learning models think pair share can improve students' critical thinking skills in social studies learning. It means that the application of the think pair share learning model can improve student learning outcomes on the subject of changes in space and interaction between spaces due to natural factors in class VIII A of SMPN 2 Gresik. Thus, the study was stopped in cycle II.

The average value of students from the results of students' critical thinking ability in cycle I to cycle II experienced a very good increase. In the first cycle the results of the students' critical thinking ability were 85 and the lowest was 40 . With a complete number of students only $16(50 \%)$ and those who did not complete 16 people (50\%). While in the second cycle there was an increase, the highest score was 95 and the lowest was 55. Whereas the completeness increased which was completed to 31 people (96\%) and those who did not complete 1 student (4\%). 


\section{CONCLUSION}

Based on the results of the research that has been carried out, it can be concluded that the application of the cooperative learning model think pair share has proven to be effective in improving social science critical thinking skills of Grade VIII A students of Gresik Junior High School 2. The critical thinking ability of students in cycle I and cycle II experienced a very good improvement. In the first cycle the results of the students' critical thinking ability were 85 and the lowest was 40 . With a complete number of students only $16(50 \%)$ and those who did not complete 16 people $(50 \%)$. Whereas in the second cycle there was an increase in the highest score, which was 95 and the lowest was 55. Whereas the completeness increased which was completed to 31 people $(96 \%)$ and those who did not complete 1 (4\%). Teacher activities during the learning process with the application of cooperative learning models think pair share has increased. Student activities during the learning process with the application of cooperative learning models think pair share also increased.

Based on the above conclusions, the researcher gave some suggestions relating to the application of cooperative learning models think pair share in social studies subjects, that is, the application of the cooperative learning model think pair share can be used as an alternative learning model in an effort to improve students' social science thinking skills which are impacted on increasing results social studies learning students. It is expected that when using the cooperative learning model think pair share teachers must be able to guide students to conduct experiments so that they can make students think critically. Teachers should familiarize students with active learning activities.

\section{REFERENCE LIST}

Daryanto's. (2010). Learning and teaching. Bandung: Yrama Widya.

Ibrahim, M. (2000). Cooperative learning. Surabaya: Surabaya State University.

Julianto, D. (2011). Theory and Implementation of Innovative Learning Models.

Surabaya: University Press.

Williawati, L. (2009). The Effect of Mathematics Learning with a Discourse Approach to Students' Critical Thinking Ability in Mathematics. UNPAS: not published.

Somantri, Numan. 2001. Menggagas Pembaharuan Pendidikan IPS. Remaja Rosdakarya. Bandung

Sudjana, Nana. 2008. Penelitian Hasil Belajar Mengajar. Bandung: Rosda Karya.

Syah,M (2003).Psikologi Pendidikan.Jakarta.Rajawali Pers.

Suhardjono. 2011. Penelitian Tindakan Kelas dan Tindakan Sekolah, Malang. Cakrawala Indonesia dan LP3 Universitas Negeri Malang.

Yulianto, dkk (2008). Model-Model Pembelajaran Inovatif. Pusat Penerbitan Universitas Negeri Surabaya 
http://akhmadsudrajat.wordpress.com/2011/01/30/pembelajaran-inkuiri-sosial/ diakses 2 Januari 2015) 